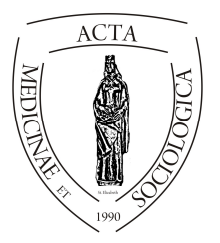

Acta Medicinae et

Sociologica (2018)

UNIVERSITY OF

DEBRECEN

Vol. 9. No. 27. (138-159)

FACULTY OF

HEALTH

doi: 10.19055/ams.2018.9/27/10

NYÍREGYHÁZA

\title{
Az önkormányzati segélyezési rendszer változásai és azok hatásai 2008 - 2018 között egy nagyváros példáján keresztül
}

\author{
Krizsai Anita $^{1}$, Tóthné Csatlós Ildikó ${ }^{2}$ \\ ${ }^{1}$ irodavezető, jogtanácsos, Nyíregyháza Megyei Jogú Város Polgármesteri Hivatal, Szociális és Köznevelési Osztály \\ ${ }^{2}$ csoportvezető, Polgármesteri Hivatal, Szociális és Köznevelési Osztály Társadalompolitikai csoport
}

\section{INFO ABSTRACT}

\section{Krizsai Anita \\ krizsai.anita@nyiregyhaza.hu}

The changes the practice of the social benefit system and its' effects for the local population from 2008 to 2018 in an example of a big town. The recent changes of the social administration and social benefit system caused new situations and new issues for the level of the local governments. All these administrational reforms could be more understood in the context of the changes of the social status of local citizens. The research conducted in the cooperation of the local government of Nyíregyháza and the University of Debrecen, Faculty of Health called "Quality of life in Nyíregyháza" provided good opportunity to follow the quality of life of local citizens. We could also focus on the effects of the local social administration, especially the targeting and efficacy of social benefits. Despite the stability of the local social benefit system newest results showed decreasing number of benefit users. This study we examined the main reasons of the process in the context of the economic and social status and the attitudes of using social benefits.

\section{Kulcsszavak}

helyi szociális ellátórendszer, hozzáférés, célzottság, a szociális ellátórendszer változásai
Absztrakt. A szociális ellátások és segélyezési rendszer 2015 óta bekövetkezett változásai új helyzetet eredményeztek, melyre az önkormányzati segélyezési rendszernek is reagálnia kellett. Az igazgatási reformok hatásai nem vizsgálhatók a helyi lakosság szociális helyzetének elemzése nélkül. A Nyíregyháza Megyei Jogú Város és a Debreceni Egyetem Egészségügyi Kara együttmüködésében megvalósuló "Nyíregyháza Város Életminősége" kutatássorozat lehetőséget nyújt a lakosság életminőségének vizsgálatára. (Fábián, Huszti, Hüse, Takács (2018); Huszti, Hüse, Takács Fábián, (2018)) A kutatás során az életminőség egyes elemeinek vizsgálatán túl elemezni tudtuk a szociális ellátások 
igénybevételének gyakorlatát, célzottságát, hatásosságát. Annak ellenére, hogy a helyi szociális ellátások és támogatások rendszere megőrizte stabilitását, a legújabb eredmények csökkenő igénybevételi rátákat mutattak. Ebben a tanulmányban megvizsgáljuk a fenti folyamatok főbb okait a mintába került lakosság szociális, gazdasági jellemzőinek elemzésével, valamint a segélyezéssel kapcsolatos attitüdök változása tükrében.

Ez a tanulmány a Nyíregyháza város életminősége - Háztartáspanel kutatás Egészségi állapot felmérése keretében készült.

\section{Bevezetés}

Tanulmányunkban arra teszünk kísérletet, hogy bemutassuk a segélyezési rendszerben 2008 óta bekövetkezett változásokat, annak hatásait, hogyan érintették ezek a folyamatok a város lakosságát, valamint arra keresünk választ, hogy milyen folyamatokkal indokolhatók a 2015 óta végbement változások.

A szociális igazgatásról és a szociális ellátásokról szóló 1993. évi III. törvény (továbbiakban: Szt.), valamint a gyermekek védelméről és a gyámügyi igazgatásról szóló 1997. évi XXXI. törvény (továbbiakban: Gyvt.), az ezekhez kapcsolódó Kormány rendeletek és egyéb kapcsolódó jogszabályok tartalmazzák az állam és az önkormányzat által biztosított egyes pénzbeli és természetbeni szociális és gyermekvédelmi ellátások formáit, $\mathrm{s}$ az ellátásokra való jogosultság feltételeit.

A rendszerváltást követően a szociális igazgatásban végbemenő változások fö iránya a szociális ellátások decentralizálása, többek között a települési önkormányzatok segélyezési rendszerének kiépítése volt. ${ }^{1}$ A megjelenő jogszabályok az önkormányzatokat hatalmazták fel arra, hogy az egyes ellátások feltételeit, az igénylésre vonatkozó eljárási szabályokat a helyi sajátosságokat figyelembe véve rendeletükben határozzák meg. Lényegi elemmé vált, hogy helyi szinten az önkormányzatok milyen jellegü és rendszerességű ellátásokkal igyekeztek hatékonyan csökkenteni lakosainak a foglalkoztatottság hiányából, a lakhatási problémák nehézségeinek kiküszöböléséből, egyéb, az élet nyújtotta speciális helyzetekből és anyagi nehézségekből adódó problémákat.

Ennek a folyamatnak az eredményeképpen önkormányzatonként eltérő segélyezési gyakorlat alakult ki, mely felett államigazgatási kontroll sem létezett, az esetleges elutasítások ellen bírósághoz fordulhattak az ügyfelek. Ennek hatására az Szt. 1996-ban és 1997-ben is jelentősen módosult, a segélyezés terén a normatívabb, kevésbé diszkrecionális szabályozás bevezetése történt. Erre volt példa az időskorúak járadékának 1998. január 1-től történő bevezetése vagy a lakásfenntartási támogatás szabályainak módosítása, mely már nem adott mérlegelési lehetőséget az önkormányzatok számára a támogatások megállapításában.

\footnotetext{
${ }^{1}$ A cél, hogy „a korábban egyeduralkodó központi elosztás rugalmatlanságával és elkerülhetetlen pazarlásaival szemben testre szabottá váljék a rászorulók szükségleteinek felmérése és kielégítése, valamint csökkenjenek és ésszerübben hasznosuljanak a szociális ellátásra fordítható források." (Szalai, 2002)
} 
A következő jelentősebb változás 2005/2006-ban zajlott le, amikor az addig önkormányzati hatósági ügyként kezelt ellátások közül a rendszeres szociális segély, az időskorúak járadéka és a normatív ápolási díj megállapítására vonatkozó hatáskör a jegyzőkhöz került, akik így átruházott hatáskörben államigazgatási feladatként láttak el segélyezési feladatokat. Ez együtt járt ezen támogatási típusok esetén az államigazgatási kontroll megteremtésével. Az önkormányzatoknál így kettős rendszer alakult ki, egyes ellátástípusok esetén (többnyire normatív alapon járó támogatások) államigazgatási hatáskörben a jegyző járt el, míg a többi ellátás típusnál a hatáskör címzettje továbbra is a képviselö-testület maradt.

A szociális ágazatot érintő újabb és talán legjelentősebb változásokra 2010-es évektől került sor. Elöször a személyes gondoskodást nyújtó szakellátások „,viszszaállamosítása" történt meg. A segélyezési rendszer átalakításának alapja a járási hivatalok felállítása volt, így időben később csak 2013. 01. 01. napjától a hivatalok felállásával valósult meg (országosan 175 járás és 23 kerületi hivatal jött létre) az államigazgatási feladatként szabályozott szociális támogatások államhoz kerülése, az eddig a jegyzőkhöz tartozó ügyek egy részét a járási hivatalok vették át. A törvényalkotók álláspontja az volt, hogy az új rendszer képzettebb munkaerőt biztosít, s felgyorsítja az ügyintézés folyamatát. A cél az egyablakos ügyintézés biztosítása az ügyfelek számára. 2013. január 01. napját követő változásokkal a jegyző hatásköréből a járási hivatalokhoz került az időskorúak járadéka, alanyi és normatív közgyógyellátásra jogosultság (Szt. 50.§ (1)-(2) bekezdés), ápolási díj (43/B.§ kivételével), és az egészségügyi szolgáltatásra való jogosultság (Szt. 54. §). Jegyzői hatáskörben maradt az aktív korúak ellátására jogosultság, a lakásfenntartási támogatás és az önkormányzat rendelete szerinti közgyógyellátásra jogosultság (Szt. 50. $\S(3)$ bekezdés).

Az újabb módosításokkal, melyre 2015. március 01-től került sor, az állam és az önkormányzatok segélyezéssel kapcsolatos feladatai egyértelműen elváltak egymástól. Ezt követően az úgynevezett jövedelem kompenzáló támogatások a járási hivataloktól, a kiadáskompenzáló támogatások a települési önkormányzatoktól igényelhetők. A járásoktól kérhető jövedelemkompenzáló támogatások közé tartozik a közgyógyellátás, az ápolási díj, az időskorúak járadéka, az egészségügyi szolgáltatás szociális rászorultság alapon, aktív korúak ellátása (foglalkoztatást helyettesítő támogatás és egészségkárosodási és gyermekfelügyeleti támogatás). A jövedelemkompenzáló támogatásokat 2015. márciustól teljes egészében a központi költségvetésből finanszírozzák. A jogosultságot ezekhez a támogatásokhoz a járási hatóságok állapítják meg, országosan egységes elvek alapján.

A lakásfenntartási támogatás, az adósságkezelési szolgáltatás, a méltányossági ápolási díj, a méltányossági közgyógyellátás szabályai 2015. március 1-étől kikerültek a szociális törvényből. Ettől az időponttól kezdődően a támogatás ebben a formában nem állapítható meg a kérelmezők részére.

Az önkormányzatoktól kérhető kiadáskompenzáló támogatások elnevezése 2015. márciustól egységesen „települési támogatás” lett, ebbe a kategóriába sorolhatók az egyszeri segélyek, a rendszeres gyógyszertámogatás, a lakásfenntartási támogatás, az adósságkezelési szolgáltatás, a 18 év feletti személyek ápolására nyújtható ápolási díj. A települési támogatáson felül az Szt. 26. §-a alapján a települési önkormányzat képviselö-testülete a hatáskörébe tartozó pénzbeli ellátásokat kiegészítheti, és a szo- 
ciálisan rászorultak részére - a rendeletében meghatározott módon és feltételek szerint - más pénzbeli támogatásokat is megállapíthat.

A fenti támogatások közül a lakásfenntartási támogatás megszüntetése a legvitathatóbb, hiszen ez volt szinte az első olyan támogatás típus, melynél a normatív szabályozást bevezették. A normatív szabályozás egyik indoka volt a lakhatáshoz való jog, mint alapjog biztosításának a segítése, másrészt a kutatási adatok alapján az élelmiszert követően a legtöbb kiadást a háztartások számára a lakásfenntartás költségei jelentik. Az országos adatok alapján a lakásfenntartási támogatásban részesülő háztartások száma 2000-től folyamatosan emelkedett, 2012-ben vették legtöbben igénybe (498.931). (KSH). Nyíregyháza város adatai alapján szintén az egyik legtöbbet igényelt támogatási forma volt 2012-ig.

\begin{tabular}{|l|l|l|l|l|l|l|}
\hline & 2008 & 2010 & 2012 & 2014 & 2016 & 2017 \\
\hline $\begin{array}{l}\text { Lakásfenntartási támogatás } \\
\text { (háztartás) }\end{array}$ & 3057 & 4429 & 5828 & 4448 & 1811 & 1905 \\
\hline $\begin{array}{l}\text { Rendkívüli települési tá- } \\
\text { mogatás (2015 elött átme- } \\
\text { neti segély, temetési se- } \\
\text { gély, rendkívüli gyermek- } \\
\text { védelmi támogatás) (eset- } \\
\text { szám) }\end{array}$ & 6984 & 9052 & 7362 & 8209 & 6420 & 6558 \\
\hline
\end{tabular}

1. táblázat: lakásfenntartási támogatásban és rendkívüli települési támogatásban részesülő háztartások/személyek száma (2008-2017).

Az országos adatok alapján 2013-tól folyamatosan csökkent a támogatott háztartások száma (385.074), majd az újabb jogszabályi változások eredményeképpen szintén tovább csökkent (2015-ben 333.149 háztartás) (KSH). A városi adatok az országos tendenciát követik, bár városunkban jelentősebb mértékben, a harmadára csökkent (2018-ban már csak 1487) a lakásfenntartási támogatásban részesülők száma. A változás annak ellenére bekövetkezett, hogy a korábbi, Szt. szerinti szabályozást fenntartottuk, majd ezt követőn figyelembe véve a garantált bérminimum és a nyugdíjak összegének növelését, emeltük a jogosultság feltételeként a jövedelemhatárt.

A TÁRKI kutatás szintén hasonló eredményt mutatott ki, vizsgálatuk alapján a lakhatási célú támogatást igénybe vevők száma 35 \%-ról $19 \%$-ra csökkent. A kutatók vélekedése szerint ennek oka, hogy a korábban normatív módon nyújtott támogatásról az önkormányzat saját hatáskörben dönthet, így sokan kiszorulnak a támogatásból. (Kopasz, Gábos, 2018) Véleményünk szerint nem feltétlenül ez lehet az ok, hiszen Nyíregyházán a korábbiakhoz képest is kedvezőbb jogosultsági feltételeket állapítottunk meg.

A csökkenés egyik oka lehet, az adósságkezelési szolgáltatás Szt. szerinti szabályainak változása, majd 2015. március 1-től megszünése, hiszen a jogosultak számára alanyi jogon járt a lakásfenntartási támogatás (2010-ben a támogatottak $30 \%$-át tették ki). A 2012. január 1-től bevezetett szigorítással 24 hónapig, illetve 48 hónapig nem volt kérelmezhető a támogatás azok számára, akik egyszer már részesültek 
a támogatásban, illetve, akik az együttmüködési kötelezettségüket megszegték így számuk 2011-ről 2012-re 1583 főről 379-re csökkent. Annak ellenére, hogy a törvényi szabályozás megszüntetését követően önkormányzatunk biztosította e támogatási formát szankció nélkül, nem növekedett jelentősen a támogatottak köre (2017-ben 143 fö, 2018-ban 95 fö).

Ha csak az átrendeződést követően a 2015-2018 közötti időszakot vizsgáljuk az országos adatok alapján a települési támogatásban részesülök száma növekedett (463.599 föről 609.388 före) a KSH adatai alapján. Átlagosan a támogatáskánt kapott összeg $6859 \mathrm{Ft}$ volt 2017 évben. (KSH) Nem egyértelmü, hogy a települési támogatásba a rendkívüli települési támogatás is beletartozik-e, vélhetően igen. A TÁRKI kutatása alapján 2014 és 2016 között elmozdulás történt a rendszeresen adható támogatások felől az eseti jelleggel, a rendkívüli települési támogatás keretében adható támogatások felé. Érdemben nem változott a vizsgált ellátásokban részesülők együttes száma, de 2016-banban számottevően kevesebben részesültek lakhatási támogatásban és csökkent az ápolási támogatás igénybevétele is. Eközben jelentősen növekedett az egyéb önkormányzati támogatásban részesülök száma. A támogatásokra fordított kiadások összege ugyanakkor 2016-ra reálértéken a 2014-es szint 70 százalékára esett vissza. Elsősorban a lakhatásra fordított kiadások mértéke csökkent, de kevesebbet fordítottak az önkormányzatok gyógyszertámogatásra és ápolási támogatásra is (Kopasz, Gábor, 2018).

Az 1. táblázat adatai alapján látható, hogy az átmeneti segélyt, temetési segélyt és rendkívüli gyermekvédelmi támogatást felváltó rendkívüli települési támogatásra jogosultak számát és az esetszámot vizsgálva 2010 és 2017 között nem következett be jelentősebb változás városunkban. A méltányossági ápolási díj és a gyógyszertámogatás esetén a jogosultak száma 2017-re növekedett majd 2018- ra csökkent (386 és 586 föröl 95 és 292 före).

\begin{tabular}{|l|l|l|l|l|l|l|}
\hline & 2008 & 2010 & 2012 & 2014 & 2016 & 2017 \\
\hline ápolási díj & 516 & 532 & 600 & 799 & 1214 & 1073 \\
\hline méltányossági ápolási díj & 409 & 466 & 637 & 575 & 363 & 386 \\
\hline közgyógyellátás & 4522 & 2696 & 3712 & 3742 & 4046 & 5783 \\
\hline gyógyszertámogatás & - & - & - & - & 519 & 586 \\
\hline aktív korúak ellátása $^{2}$ & 1994 & 3540 & 5738 & 4317 & 3189 & 2361 \\
\hline
\end{tabular}

Forrás: Polgármesteri Hivatal, Járási Hivatal Nyíregyháza

2. táblázat: Nyíregyháza közigazgatási területén támogatásban részesülők száma (fö).

\footnotetext{
${ }^{2}$ Aktív korúak ellátása tartalmazza a foglalkoztatást helyettesítő támogatás és az egészségkárosodási és gyermekfelügyeleti támogatásban részesülők számát. (2009. január 1-ig rendszeres szociális segélyezettek, ezt követően rendszeres szociális segélyezettek és a rendelkezésre állási támogatottak. 2011. január 1-jétől a rendelkezésre állási támogatás helyett bérpótló juttatásra jogosultak.)
} 
A 2. táblázat adatai alapján látható, hogy 2008 és 2012 között folyamatosan emelkedett a támogatásban részesülők száma, 2012-ben elérve a maximumot, majd csökkenés következett be. Ennek magyarázata lehet a jövedelmi szegénység növekedése majd csökkenése. A Tárki adatai alapján a gazdasági és pénzügyi válság hatására 2007 és 2012/2013 között növekedtek az egyenlőtlenségek, és ezzel párhuzamosan a jövedelmi szegénység is (a Tárki adatai szerint 2007 és 2012 között 12,6 százalékról 17 százalékra, a KSH adatai szerint 2007 és 2013 között 12,3 százalékról 15 százalékra). A válságot követően azonban mindkét mérőszám esetében számottevő csökkenést figyelhetünk meg: a KSH adatai szerint előbbi 15 százalékról 13,4 százalékra, utóbbi pedig 28 százalékról 16 százalékra csökkent. Többváltozós statisztikai elemzésük alapján a válság enyhülésével elsősorban az általában magasabb státusúak (másképpen az alsóközép-és középosztály) helyzete javult, akik a pénzügyi és gazdasági krízis során csak átmenetileg kerültek nehéz körülmények közé ( Branyiczki, Gábos, 2018).

A KSH adatai alapján 2010-hez hasonlóan 2017-ben is a munkanélküliek között a legmagasabb a szegénység kockázata (1. ábra).

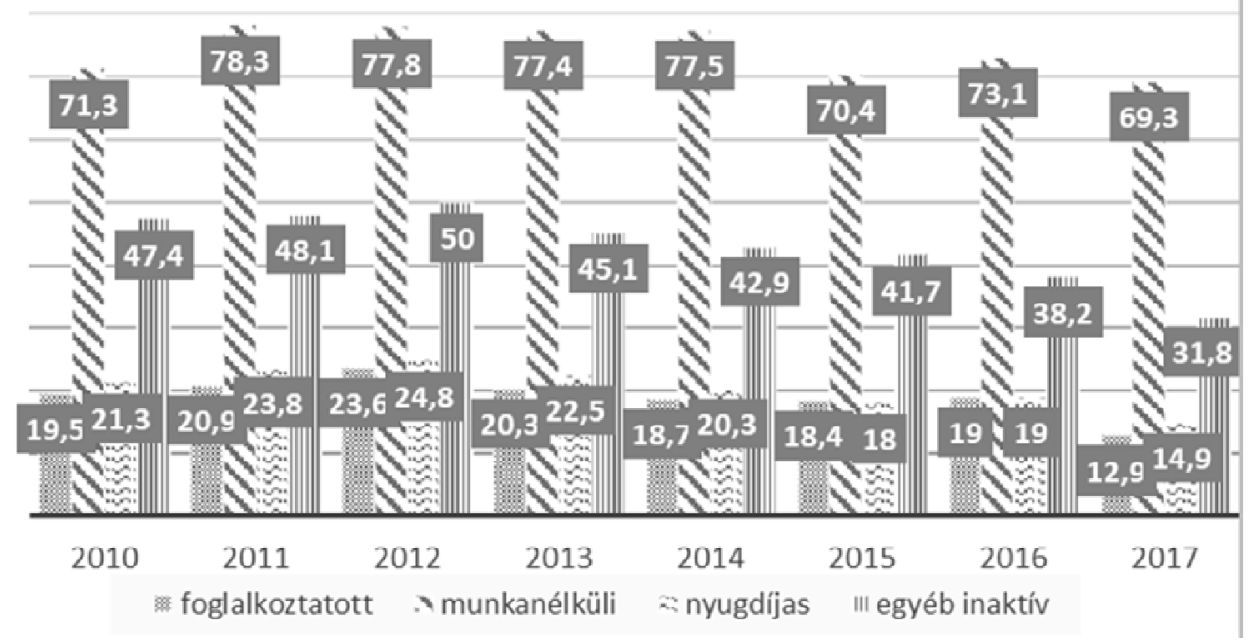

Forrás: KSH, saját szerkesztés

1. ábra: Szegénység vagy társadalmi kirekesztődés kockázatának kitettek aránya a legjellemzőbb gazdasági aktivitás szerint.

A munkanélküliség mind országosan mind városunkban kedvezően alakult, 2012-től jelentősen csökkent nemcsak a nyilvántartott álláskeresők és tartós munkanélküliek száma, hanem a segélyezetteké is (2. ábra). 


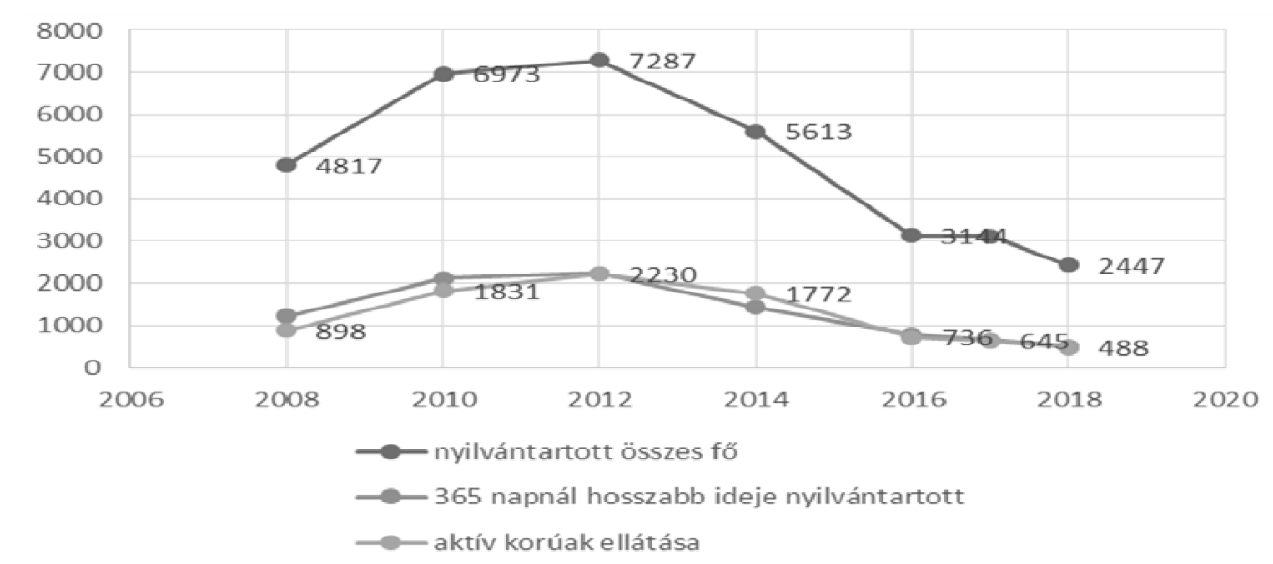

Forrás: Nemzeti Foglalkoztatási Szolgálat, saját szerkesztés

2. ábra: A nyilvántartott álláskeresők száma tartózkodási helyük szerint, Nyíregyháza.

A kedvező tendencia egyik oka a 2011-töl átalakított közfoglalkoztatás. A közfoglalkoztatásban részt vevő személyek havi átlagos száma 122913 fö volt 2018 novemberében, a résztvevők havi átlagos létszáma Borsod-Abaúj-Zemplén (23 372 fö) és Szabolcs-Szatmár-Bereg (22 516 fö) megyékben volt a legmagasabb. A vizsgált hónapban hosszabb idejü közfoglalkoztatásban dolgozott a résztvevők 43,5 százaléka az országos arányt tekintve. A hosszabb ideig közfoglalkoztatók között megyénk nem szerepelt. A közfoglalkoztatás nyilvántartott álláskeresőkhöz viszonyított súlya ${ }^{3} 2018$ novemberében azonban Szabolcs-Szatmár-Bereg megyében $(46,7 \%)$ volt a legmagasabb és a legalacsonyabb értékkel Budapest (7,9\%) és Pest megye $(14,7 \%)$ rendelkezett. A közfoglalkoztatási ráta országos értéke 33,5 százalék volt ebben az időszakban. ${ }^{4}$

A nyíregyházi adatokat tekintve 2015 évhez képest közel duplájára növekedett a közfoglalkoztatottaknak a nyilvántartott álláskeresőkhöz viszonyított aránya (18\%ról $35 \%$-ra) annak ellenére, hogy létszámuk jelentősen nem változott (2015-ben a közfoglalkoztatottak átlagos létszáma 1256 fó, 2017-ben 1750 fö) $)^{5}$ vagyis a nyilvántartott álláskeresők számának csökkenése mögött a kedvező munkaerő-piaci folyamatok állnak.

Összességében, ha összevetjük a nyilvántartott álláskeresők közül a támogatásban részesülőket (3028-ból 1192 fö), a közfoglalkoztatottak (1750 fö) és a rendszeres pénzellátásban (ápolási díj 1459) részesülők számát, 4401 före tehető a jövedelmi helyzetük alapján biztosan rászorulók száma 2017-ben. Ugyanezt 2012-re vizsgálva (2588 fö, 1434 fö, 1237 fö) 5229 fö volt. Ha összevetjük az egyéb támogatási formában részesítettek számával (2017-ben 1905 háztartás kapott lakásfenntartási

\footnotetext{
${ }^{3}$ A közfoglalkoztatásban részt vevők havi átlagos létszáma/(nyilvántartott álláskeresők zárónapi száma + közfoglalkoztatásban részt vevők havi átlagos létszáma).

${ }^{4}$ Havi tájékoztató a közfoglalkoztatás alakulásáról 2018. november Belügyminisztérium Közfoglalkoztatási és Vízügyi Helyettes Államtitkárság.

${ }^{5}$ A legalább egy napig közfoglalkoztatottak száma 3335 fő volt 2017-ben.
} 
támogatást, 1297 fö/háztartás részesült rendkívüli települési támogatásban), vélhetöen kialakult egy olyan réteg, melyet az önkormányzat folyamatosan támogat.

Ugyanakkor figyelembe véve a helyi rendeletünkben megállapított jövedelemhatárokat, álláspontunk szerint többen lennének jogosultak az egyes támogatási típusokra, ezért a továbbiakban azt vizsgáljuk milyen egyéb okokra vezethetők vissza a segélyezettek számának csökkenése.

\section{A gyermekes háztartások helyzete}

A rendszeres gyermekvédelmi kedvezményben részesülők száma nagyságrendileg a lakásfenntartási támogatáshoz hasonló mértékü volt. A tanulmány alapját képező kutatás keretében elsősorban a szociális, pénzbeli és természetbeni ellátásokra és szolgáltatásokra vonatkozó kérdések szerepelnek. Azonban az előzőekben említettek szerint a gyermekek a családok részét képezik, életük nem választható el a családtól, és így a család nélkülözése, rászorultsága a gyermek szegénységét is jelenti.

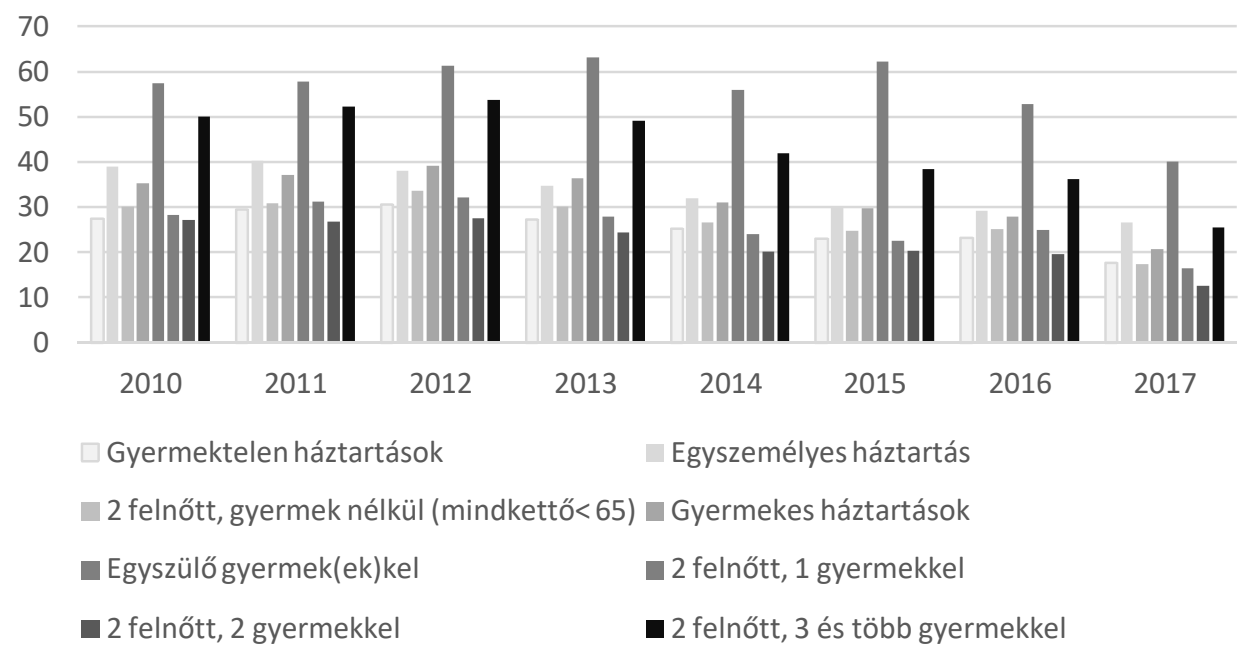

Forrás: KSH, saját szerkesztés

3. ábra: Szegénység vagy társadalmi kirekesztődés kockázatának kitettek aránya háztartástípusok szerint 2010-2017.

A Gyvt-ben meghatározott rendszeres gyermekvédelmi kedvezmény célja, annak igazolása, hogy a gyermek jogosult ingyenes vagy kedvezményes étkeztetésre, tankönyv támogatásra vagy egyszeri támogatásra. Valamint a Gyvt-ben nem meghatározott esetekben is például ösztöndíj programokban, felsőfokú tanulmányokra való jelentkezés esetén előnyt jelent a kedvezményre való jogosultság ténye.

Habár a különböző jelentések szerint a magyar gyermekek körülbelül harminc százaléka nélkülözik, minden harmadik-negyedik gyerek éhesen megy iskolába, nem jut megfelelő táplálékhoz mégis a rendszeres gyermekvédelmi kedvezményben 
- abban a támogatási formában amely alapvetően étkeztetésre jogosít - részesülök száma csökken. Ez országosan is igaz, és Nyíregyháza városban is kimutatható a negatív tendencia. A létszám csökkenés okait részletesen vizsgálta Farkas Zsombor (Farkas, 2016). Farkas megállapítása szerint egyrészt a családok kismértékü jövedelem növekedése és a kedvezményre való jogosultsági küszöb állandósága, másrészt demográfiai változások vezetnek a támogatásban részesülők számának csökkenéséhez (3. ábra).

Nyíregyháza önkormányzata a helyi segélyezési rendszer alakítása során igyekszik nyomon követni mindazokat a társadalmi, gazdasági és jogi változásokat, amelyek hatással bírnak a szociális és gyermekjóléti ellátások rendszerére. A kétévente ismétlődő helyi szociológiai kutatás, a statisztikai adatok és a jogszabályi környezet alapján az önkormányzat célja, hogy jól célzott, a támogatásra szoruló egyéneknek, családoknak valós segítséget nyújtó támogatási rendszert alakítson ki.

A rendszeres gyermekvédelmi kedvezményben részesülők számának csökkenése évek óta megfigyelhető Nyíregyházán. Érdekes a háttér vizsgálata, még akkor is, ha úgy tünik e mögött valóban a jogosultsági jövedelem határ állandósága és a demográfiai változások állnak. Tanulmányunkban megvizsgáljuk ezt a két dimenziót, valamint feltesszük azt a kérdést, hogy a létszámcsökkenés jelenti-e, hogy kevesebb a rászoruló gyermek és családja, vagy azt jelenti, hogy helytelen jogi szabályozás miatt a rászorulók kiesnek a támogatási rendszerekből, vagy pedig a támogatási rendszerek változása miatt más módon jutnak azokhoz a kedvezményekhez, amelyek a rendszeres gyermekvédelmi kedvezményhez is kapcsolódnak.

Nyíregyháza lakónépessége 117-118 ezer fö, stagnálás jellemző. A korstruktúra az országos tendenciákat követi, a gyermekkorú népesség aránya csökken, az idősek számaránya növekszik. A 0-19 évesek aránya a lakónépességen belül 1990-ben 32,2 \%, 2000-ben 25 \%, 2010-ben 20,4 \% (Malakucziné Póka M., 2012).Hosszabb időszakot vizsgálva a változás jelentős, a tanulmány által vizsgált 2008-2017 között időszakban a 0-18 évesek aránya 19,7- 20,4 \%. Számokban meghatározva közel 1000 fó a gyermekkorúak fogyása a megyei jogú város népességén belül.

\begin{tabular}{|c|c|c|c|c|c|c|}
\hline & 2008 & 2010 & 2012 & 2014 & 2016 & 2017 \\
\hline $\begin{array}{c}\text { lakónépesség } \\
\text { január 1-jén }\end{array}$ & 117.597 & 117.852 & 117.658 & 118.164 & 118.058 & 117.689 \\
\hline $0-18$ éves gyermekek \\
száma & 23.679 & 24.111 & 23.358 & 23.711 & 23.228 & 23.210 \\
\hline $\begin{array}{c}\text { rendszeres gyermekvé- } \\
\text { delmi kedvezményben } \\
\text { részesülök aránya a 0- } \\
18 \text { évesek számához } \\
\text { viszonyítottan }\end{array}$ & 4650 fó & 5793 & 5675 fö & 4263 fó & 3706 fö & 2741 fo \\
\hline
\end{tabular}

Forrás: Magyarország Közigazgatási helynévtára, Polgármesteri Hivatal, Nyíregyháza

3. táblázat: Nyíregyháza lakónépessége, a 0-18 évesek száma és a rendszeres gyermekvédelmi kedvezményben részesülők száma és aránya 2008-2017 között.

A rendszeres gyermekvédelmi kedvezményben részesülők számának csökkenése az elmúlt 10 évben azonban jelentős (3. táblázat). 2008-ban közel ötezer gyermek volt 
jogosult a támogatásra, 2012-ben több mint 5,5 ezer fó és 2017-re 2.741 főre esett vissza a kedvezményezettek száma. A 2012. évi és 2017. évi adatokat összehasonlítva -amikor a legmagasabb és a legalacsonyabb a támogatásban részesülők száma az egyenleg közel -3000 fó, százalékosan -12\%. A nyíregyházi adatok az országos adatokhoz hasonlóan alakulnak. Magyarországon 2008-ban 513.070 gyermek, 2012ben 572.184 fö, és 2015-ben 442.238 gyermek részesült támogatásban. 2011-2012ig növekvő, majd csökkenő tendencia figyelhető meg. 2008-2015 között 70 ezerrel csökkent a támogatottak száma az országban (Szociális Statisztikai Évkönyv, 2015).

\section{A rendszeres gyermekvédelmi kedvezményben ré- szesülök családjainak jövedelmi viszonyai Nyír- egyházán}

A települési önkormányzat jegyzőjének feladatai közé tartozik a Kimutatás a pénzben és természetben nyújtható támogatások adatairól címü kérdőív (nyilvántartási száma 1206) kitöltése évenként, amely az Szt. és Gyvt. alapján megállapított támogatásokról ad részletes információkat, többek között a rendszeres gyermekvédelmi kedvezményben részesülőkre vonatkozóan (ellátottak száma, támogatást kérők száma, elutasítások, a családok jövedelmi viszonyai stb.) (4. táblázat).

\begin{tabular}{|c|c|c|c|c|}
\hline \multirow{2}{*}{} & \multicolumn{2}{|c|}{$\begin{array}{c}\text { rendszeres gyermekvédelmi kedvezményre jogosult gyermekek } \\
\text { száma az egy före jutó családi jövedelem szerint }\end{array}$} & \multirow{2}{*}{$\begin{array}{c}\text { elutasítások } \\
\text { száma }\end{array}$} \\
\cline { 2 - 4 } & $14.250 \mathrm{Ft}$ alatt & $14.250-28.500$ & $28.500-$ & \\
\hline 2008 & & & & \\
\hline 2010 & 435 & 3485 & 1873 & 288 \\
\hline 2012 & 638 & 3243 & 1521 & 275 \\
\hline 2014 & 566 & 2440 & 1257 & 249 \\
\hline 2016 & 464 & 2114 & 1123 & 215 \\
\hline 2017 & 314 & 1507 & 601 & 229 \\
\hline
\end{tabular}

Forrás: Polgármesteri Hivatal, Nyíregyháza

4. táblázat: A rendszeres gyermekvédelmi kedvezményre jogosult gyermekek száma az egy főre jutó családi jövedelem szerint Nyíregyházán 2008-2017 között.

A Gyvt. 19. § (2) bekezdése alapján rendszeres gyermekvédelmi kedvezményre jogosult a gyermek, amennyiben a gyermeket gondozó családban az egy főre jutó havi jövedelem összege nem haladja meg az öregségi nyugdíj mindenkori legkisebb összegének meghatározott százalékát. 2008-ban a százalékos korlátok $125 \%$ és 135 \% (egyedülálló, tartós beteg, nagykorú), 2009. szeptember 1-től ez $130 \%$ és 140 \%ra változott. 2018. január 1-től a jövedelemhatár $135 \%$ és $145 \%$.

A statisztikai adatok szerint Nyíregyházán a kedvezményben részesülő gyermekek családjaiban az egy före jutó jövedelem 14.250 -28.500 Ft között volt. A létszám a legmagasabb kategóriában csökkent a leginkább, harmadára esett vissza a 
támogatotti létszám. Az alsó két kategóriában- ha a legmagasabb és legkisebb létszámot tekintjük - 50 \%-os csökkenés tapasztalható.

Mivel a támogatásban részesülők száma csökken és az elutasítások száma nem növekszik, ebből egyértelmüen megállapítható, hogy a támogatást kérők száma is csökken. Ellenkező esetben az elutasítások számának növekednie kellene.

\section{Miért nem igénylik a rendszeres gyermekvédelmi kedvezményt?}

Farkas - 2010-2014 közötti időszakot vizsgálta - álláspontja szerint az igénybe vevők számának visszaesését a korábban jogosult családok kismértékü jövedelemnövekedése okozza (Farkas, 2016). A nyíregyházi, helyi Életminőség kutatás eredményei az állítást alátámasztják részben. Fábián - Takács - Szigeti szerint Nyíregyházán „A 2010 és 2012 közötti periódus a válságból való kilábalás időszaka volt, nőtt a foglalkoztatottak aránya, nominális értékben is nőttek a jövedelmek (a növekedés mind a háztartásokra jutó összjövedelem, mind az egy főre jutó jövedelmek esetében mérhető volt), a szegénységben élök aránya is enyhe csökkenést mutatott, és az FTI értékei is kedvezőbbek lettek (Fábián, Takács, Szigeti, 2015).

A kedvező tendenciák folytatódtak 2012 és 2015 között is, nőttek a nettó jövedelmek, a növekedés pedig nemcsak „szétterült” a város társadalmi terében, hanem jelentős emelkedést mutatott a legalsó decilis esetében" (5. táblázat) (Fábián, Takács, Szigeti, 2015).

\begin{tabular}{|c|c|c|c|}
\hline & 2012 & 2015 & $\%$ \\
\hline Alsó decilis & 22,487 & 29,057 & $+29,0$ \\
\hline 2. Decilis & 38,359 & 43,864 & $+14,0$ \\
\hline 3. Decilis & 48,482 & 50,835 & $+4,8$ \\
\hline 4. Decilis & 56,787 & 62,552 & $+10,0$ \\
\hline 5. Decilis & 63,748 & 73,173 & $+14,8$ \\
\hline 6. Decilis & 72,450 & 81,604 & $+12,6$ \\
\hline 7. Decilis & 81,211 & 90,697 & $+11,7$ \\
\hline 8. Decilis & 95,185 & 100,007 & $+1,0$ \\
\hline 9. Decilis & 113,259 & 113,571 & $+0,3$ \\
\hline Felső decilis & 174,524 & 217,818 & $+25,0$ \\
\hline S10/S1 & 7,7 & 7,5 & \\
\hline
\end{tabular}

Forrás: Fábián-Takács, 2015

5.táblázat: A jövedelmek egyenlőtlenségei Nyíregyháza városában - az egy före jutó háztartási jövedelmek eloszlása a jövedelmi tizedek szerint, 2012-2015. (Átlagértékek, forintban) 
Szilicsány tanulmányában azért rámutat, hogy „,a szegénységi küszöb fölött élőket is érinti a szükösség, a nélkülözés, mégpedig elég jelentős mértékben, és közöttük mintegy fele-fele arányban vannak azok, akik éppen érintettek, és valószínüleg a deprivációból kifelé tartanak, valamint azok, akiket az anyagi depriváció súlyos formája érint, és a tartós szegénységtől, a kirekesztettségtöl csupán jövedelmük „nagysága” óvja, vagyis dolgozó szegények. A szegényekről is kiderült, hogy van náluk még szegényebb, akit nem csupán a nélkülözés súlyos halmozódása nyomorít, de ehhez a jövedelem hiánya is társul, ami a szegénység és kirekesztettség tartóssá válását is jelenti számukra" (Szilicsány, 2015).

A 2017-es adatfelvétel szerint az, ,átlagjövedelem növekedésének üteme 2017-re elérte a 13 százalékos arányt. Az átlagjövedelem és a mediánjövedelem örvendetes növekedésének hátterében több makrogazdasági és makrotársadalmi változás, intézkedés áll. Ilyen volt - többek között - a minimálbér, a garantált bérminimum vagy a nyugdíjak emelése, de a város tekintetében talán a legfontosabb a foglalkoztatottság növekedése.

A városlakók szubjektív megítélése is javult, hiszen 2018-ban jóval magasabb volt azoknak az aránya 2015-höz képest, akik úgy vélekedtek, hogy javult az anyagi helyzetük, és alacsonyabb azoké, akik inkább romlásról számoltak be.

A jövedelmi helyzet javulásával a szegénység is csökkent a városban. Ez a tendencia szintén „leképezi” a hazai változásokat, hiszen hazánkban a jelzett időszakban közel 15 százalékról 12,8 százalékra csökkent a jövedelmi szegénységben élők aránya” (Fábián, Takács, Szigeti, 2018).

\section{A gyermekétkeztetés és a tankönyvellátás rendsze- rének változásai}

Az előzőekben arra utaltunk, hogy a jövedelmi helyzet javulása véleményünk szerint részben okozhatja a rendszeres gyermekvédelmi kedvezményben részesülők létszámának változását. A csökkenés további oka lehet, hogy a támogatási rendszerek változása miatt más módon jutnak azokhoz a kedvezményekhez a gyermekes családok, amelyek a rendszeres gyermekvédelmi kedvezményhez is kapcsolódnak. Ezek között meg kell említeni a gyermekétkeztetés szabályainak és a tankönyvellátás rendszerének változását.

A gyermekétkeztetésre vonatkozó szabályokat a Gyvt. tartalmazza. Az ingyenes hozzáférés folyamatosan bővült, minden évben egy évfolyammal többet fogadott be a rendszer. 2011-től a bölcsődétől a nyolcadik általános végéig biztosított az ingyenes hét közbeni étkezés a rászorulónak tekintett gyerekek számára, illetve több gyermek 50 \%-os kedvezményben részesülhet.

2015-től normatív jogcímen 100 \% -os támogatásra jogosult a szülő a bölcsődei ellátásban vagy óvodai nevelésben részesülő gyermek után,

- ha rendszeres gyermekvédelmi kedvezményben részesül, 
- tartósan beteg vagy fogyatékos, vagy olyan családban él, amelyben tartósan beteg vagy fogyatékos gyermeket nevelnek,

- olyan családban él, amelyben három vagy több gyermeket nevelnek,

- olyan családban él, amelyben a szülő nyilatkozata alapján az egy före jutó havi jövedelem összege nem haladja meg a kötelező legkisebb munkabér személyi jövedelemadóval, munkavállalói, egészségbiztosítási és nyugdíjjárulékkal csökkentett összegének $130 \%$-át ${ }^{6}$, vagy

- nevelésbe vették,

- valamint az 1-8. évfolyamon nappali rendszerü iskolai oktatásban részt vevő tanuló után, ha rendszeres gyermekvédelmi kedvezményben részesül, vagy nevelésbe vették.

A gyermekétkeztetés során az intézményi térítési díj 50\%-át normatív kedvezményként kell biztosítani

- az 1-8. évfolyamon felül nappali rendszerü iskolai oktatásban részt vevő tanuló után, ha rendszeres gyermekvédelmi kedvezményben részesül;

- az 1-8. és az azon felüli évfolyamon nappali rendszerű iskolai oktatásban részt vevő tanuló után, ha olyan családban él, amelyben három vagy több gyermeket nevelnek, tartósan beteg vagy fogyatékos gyermek után.

\begin{tabular}{|l|l|l|l|l|l|}
\hline & 2010 & 2012 & 2014 & 2016 & 2017 \\
\hline $\begin{array}{l}\text { gyermekétkeztetési kedvezmény- } \\
\text { ben részesülők száma }\end{array}$ & 5323 & 5444 & 4755 & 6501 & 6500 \\
\hline szünidei étkeztetés & 1099 & 1292 & 1501 & $1437^{* *}$ & $1356^{* *}$ \\
\hline
\end{tabular}

*2014-ben téli szünetben is biztosította az önkormányzat az étkeztetést a rászoruló gyermekek számára, összesen 649 fó részére.

A táblázat a jogosultak számát tartalmazza. Az igénybevevők száma kevesebb: 2016-ban átlagosan 550 fö, 2017-ben 609 fő vette igénybe a téli, tavaszi, nyári és őszi szünet idején az étkeztetést.

Forrás: Polgármesteri Hivatal, Nyíregyháza

6. táblázat: Ingyenes vagy kedvezményes gyermekétkeztetést, valamint a szünidei étkeztetést igénybevevők száma Nyíregyházán.

Az étkezéshez kapcsolódóan 2016. január 1-től az önkormányzatnak ingyenesen kell biztosítani a szünidei gyermekétkeztetés keretében a hátrányos helyzetű gyermek és a rendszeres gyermekvédelmi kedvezményben részesülö, halmozottan hátrányos helyzetü gyermek részére a déli meleg fóétkezést az őszi, téli és tavaszi szünet valamennyi munkanapján, a nyári szünetben legalább 43 munkanapon. Nyíregyháza Önkormányzata a korábbi években is rendszeresen részt vett a nyári étkeztetési programban, illetve a jogszabályi előírást megelőzve a téli szünetben is megszervezte a rászoruló gyermekek étkeztetését pályázati forrás igénybevételével és saját erő biztosításával. A tapasztalatok szerint 2016-tól többen jogosultak a szünidei étkezte-

\footnotetext{
${ }^{6}$ Az egy före jutó jövedelem figyelembevétele alapján 2015. szeptember 1-től vehető igénybe a kedvezmény. A jövedelemhatár 2015-ben 89.408.-Ft, 2016-ban 93.795 Ft, 2017. évben $110.225 \mathrm{Ft}$.
} 
tésre, mint az igénybevevők száma. Érdemes lenne megvizsgálni, hogy milyen okok miatt nem veszi igénybe a hátrányos és halmozottan hátrányos helyzetü szülő gyermeke részére az ingyenes étkeztetést. Nyíregyháza városban 2018-ban minden egyes igénylő számára házhoz szállították az élelmet, ennek ellenére sem 100 \%-os a jogosultak és az igénybe vevők aránya.

A 6. táblázat tartalmazza az igénybe vevők számát. Látható, hogy az ingyenesen vagy kedvezményesen étkező gyermekek száma növekszik. 2016-ban a kedvezményre jogosultak körének bővítése után az ingyenes ellátásban részesülö gyermek az összes étkezőt tekintve 41, $5 \%$, a kedvezményezettek számarányához viszonyítva a gyermekek $71 \%$-a a megyei jogú városban. A szülök tehát élnek a jogszabály adta lehetőséggel, és míg korábbi bírálatok szerint a kedvezmény igénybevétele rendkívül bürokratikus volt, a 2015. évi szabályozásnak köszönhetően ez egyszerüsödött. A gyermek a szülő (törvényes képviselö) által az intézményben benyújtott dokumentumok alapján válhat jogosulttá az ingyenes étkezésre.

A tankönyvellátás rendje szintén felmenő rendszerben bővült. A térítésmentes tankönyvellátásra első alkalommal a 2013/2014. tanévben az első évfolyamra beiratkozott tanulók voltak jogosultak, ezt követően felmenő rendszerben terjedt a 2016/2017. tanévre a teljes alsó tagozatra. A 1265/2017. (V. 29.) Korm. határozat értelmében a 2017/2018. évi tanévtől az ingyenes tankönyvellátás egy ütemben került bevezetésre az 5-8. évfolyamon, és terjedt ki a középiskola 9. évfolyama számára is. Nyíregyházán 2010-2012- ben közel 8 ezer gyermek részesült ingyenes tankönyvellátásban a korábbi szabályok alapján. A 2013/14-es évektől statisztikai adatot települési szinten nem találtunk, de a jogszabályi elöírások alapján bizonyosan bővültek a számok. Itt most a tankönyvek minőségét, a rendszer bevezetésének körülményeit nem vizsgáltuk.

A gyermekétkeztetés és a tankönyvellátás szabályainak változásai nemcsak a rászoruló gyermekeket érinti, hanem a kedvezőbb körülmények között élő gyermekeket is. Nem állítjuk, de valószínüsíthető, hogy a rendszeres gyermekvédelmi kedvezményben részesülők számának a csökkenéséhez a családok jövedelmi helyzetének változásán túl az itt bemutatott változások is hozzájárulnak. A tanulmányban az elmúlt 10 év adatait elemeztük, de más időtartamot vizsgálva egyéb szempontok is felmerülhetnek a segélyek igénybevétele kapcsán. A rendszeres gyermekvédelmi kedvezmény esetében például 2006 előtt pénzbeli ellátásként müködött a támogatás, az igénybe vevők száma magasabb volt, mint a tanulmány által vizsgált időszakban bármikor. Általános tapasztalat, hogy a pénzbeli ellátásokat kedvezőbben ítéli meg a lakosság, a természetbeni ellátások értéktelenebbek számukra. A 2017-es adatok alapján a válaszadók 86,2 \%-a a pénzbeli támogatásokat tartja megfelelőnek, a természetbeni ellátásokat mindössze 4,4\%-uk. A szünidei étkeztetés gyakorlati tapasztalata is alátámasztja ezt a tényt $\mathrm{t}$, hiszen a házhoz kiszállított, előre csomagolt, meleg ebédet sem igénylik a rászoruló családok, pedig mindössze egy igénybejelentést kell megtenni, amelynek kitöltésében a gyermekjóléti szolgálat szakemberei is segítséget nyújtanak.

A tanulmányban a jogszabályi hivatkozásokkal igyekeztünk utalni arra is, hogy bár az öregségi nyugdíjminimum összege 2008-tól változatlan - előtte minden évben növekedett a mértéke -, mégsem lehet ezt a létszámcsökkenés egyetlen okaként meghatározni. A rendszeres gyermekvédelmi kedvezmény jogosultsági hatá- 
rai százalékosan változtak; ahol 2008-ban 35.625 Ft volt a jövedelemhatár ott 2018-tól 38.475 Ft, amely esetekben pedig 38.475 Ft volt, ott ma 41.325 Ft a jogosultsági küszöb.

\section{Támogató rendszerek}

Az előző fejezetekben elemeztük a rendelkezésre álló adatok alapján az elmúlt 10 évben végbemenő folyamatokat. Ebben a fejezetben azt vizsgáltuk, hogy megállapításainkat mennyire támasztják alá a kutatási adatok.

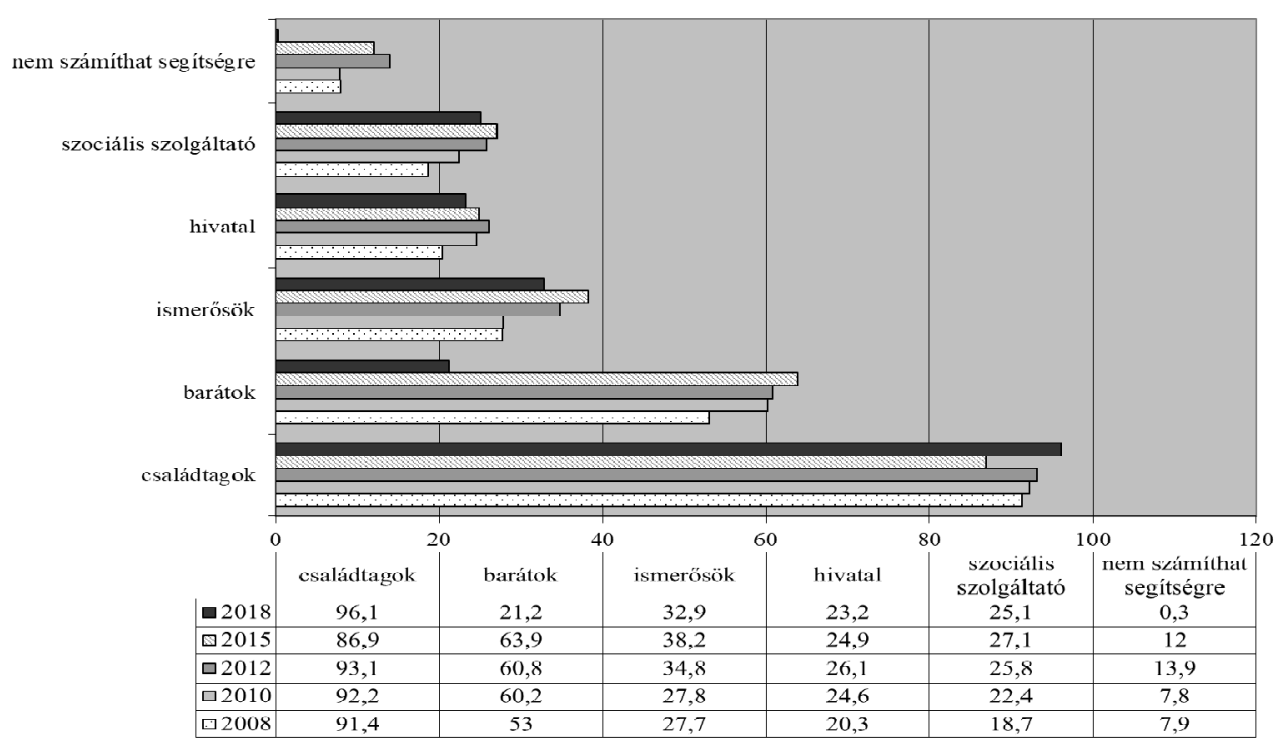

Forrás: Nyíregyháza életminösége panelkutatás, 2008, 2010, 20122015 és 2017

4. ábra: Szociális problémájának megoldásában kinek a segítségére számíthat? 2008, 2010, 2012, 2015 és $2018(\%)$

A TÁRKI kutatása alapján 2011 és 2016 közötti időszakban Magyarországon az intézményekbe vetett bizalom jelentősen növekedett. ${ }^{7}$ A segélyezési rendszer fentebb jelzett 2013-tól majd 2015 évtől végbement jelentős átalakulásával kapcsolato-

7 ,A politikai intézményekbe vetett bizalom növekedésének mértéke életkor és társadalmi státus szerint is eltérőnek bizonyult. Az átlagosnál nagyobb mértékü volt a bizalom növekedése a középkorúak (35-64 évesek) körében, és az átlagosnál alacsonyabb az idősek körében. A társadalmi státus szerint tapasztalható eltérések azt mutatják, hogy az alacsonyabb státusúak körében nött nagyobb mértékben a politikai intézményekbe vetett bizalom, a magas státusúak körében kisebb volt az emelkedés. Például az átlagosnál nagyobb mértékű bizalomnövekedést tapasztaltunk a munkanélküliek/inaktívak körében és a jövedelem szerinti legszegényebb negyedben, míg az átlagosnál alacsonyabb volt a bizalom emelkedése a felsőfokú iskolai végzettséggel rendelkezők és a magas jövedelemúek körében.” (Jakab, Gajduschek, 2016) 
san érdemes volt megnézni, hogyan változott a nyíregyházi lakosok bizalma a mesterséges támogató rendszerek iránt. Az adatok alapján a korábbi évekhez hasonlóan közel azonos a bizalom a hivatal (a járási hivatal nélkül) és a szolgáltatók iránt egyaránt Nyíregyházán. A természetes támogató rendszerek szerepét összehasonlítva továbbra is mindenhol elsődleges a család szerepe (4. ábra).

A mintán belül az idős lakosság nagyon kis mértékben fordult segítségért a hivatalokhoz (polgármesteri hivatalhoz a megkérdezett idősek $4 \%$-a. a járási hivatalhoz 2,8 \%-a). Ha összevetjük azokkal az adatokkal, mely arra kereste a választ, hogy megélhetésük hogyan alakult az elmúlt időszakban (lásd Patyán, 2018) jelentősebb számban vehettek volna igénybe támogatásokat.

Annak ellenére, hogy 2013-tól az állam szerepe a segélyezés terén felerősödött továbbra is jelentős szerepet tölt be önkormányzatunk a segítségre szorulók támogatásában. A megkérdezettek 10,7\%-a, vagyis minden tízedik megkérdezett nyilatkozott úgy, hogy fordult már segítségért az önkormányzathoz (ez 5,7 \%-a a járási hivatal esetében).

A jövedelmi viszonyok elemzésekor az látható, ahogyan az egy före jutó jövedelem emelkedik, a támogatás kérelmezése egyre ritkább. Mind a pénzbeli mind a természetbeni ellátások elsősorban a szociálisan rászorultaknak járnak, és megállapításuknál a család/háztartás egy före jutó jövedelmének nagysága és egyes ellátás típusoknál a vagyoni helyzet a meghatározó. A hivatalhoz (osztályhoz) fordulók 54,5\%-a a legalacsonyabb jövedelmi ötödhöz sorolható, 10,9\% a második legalacsonyabbhoz, 20\% a középsőhöz, 7,3\% a negyedikhez, és ugyanannyi a legfelsőhöz.

Az egy főre jutó háztartási jövedelmek alapján az alsó 5 decilisbe tartozók (legfeljebb $77990 \mathrm{Ft}$ ) jogosultak lennének segélyekre. Ugyanezt az iskolai végzettségre nézve a legfeljebb általános iskolát végzettek lehetnek segélyezettek jövedelmük alapján (64973 Ft). A szakiskola esetén már ez az összeg 88482 Ft (ezzel az összeggel még egyes támogatási típusok esetén jogosulttá válhat).

Ha a foglakoztatás szerint nézzük meg a támogatást kérelmezőket (5. ábra), alátámasztja azt az állításunkat, hogy a segélyezettek körébe elsősorban a közmunka program résztvevői tartoznak.

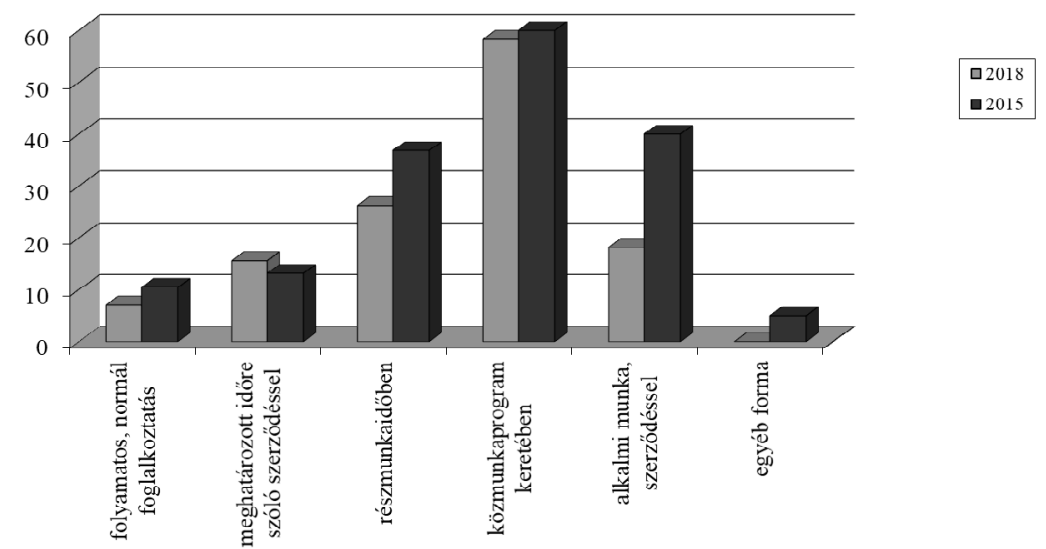

Forrás: Nyíregyháza életminősége panelkutatás, 20152018 
A válaszadók 20,3\% gondolja azt, hogy a háztartásban valaki jogosult lenne támogatásra, ugyanakkor a legalacsonyabb jövedelmüeknek is csak a $36 \%$-a kért segítséget. Továbbra is fennáll, amit 2015-ben hangsúlyoztunk, miszerint az információ hiány, alacsony érdekérvényesítő képesség, az eljárás lefolytatásához szükséges képességek hiánya (a kérelmezők 62,9 \%-a nyilatkozott úgy, hogy az igénylőlap értelmezhető) miatt sok esetben azokhoz nem jutnak el a támogatások, akik a leginkább arra rászorulnának. Ezt támasztják alá a kérelem elutasításaként a megkérdezettek által megjelölt okok (6. ábra).

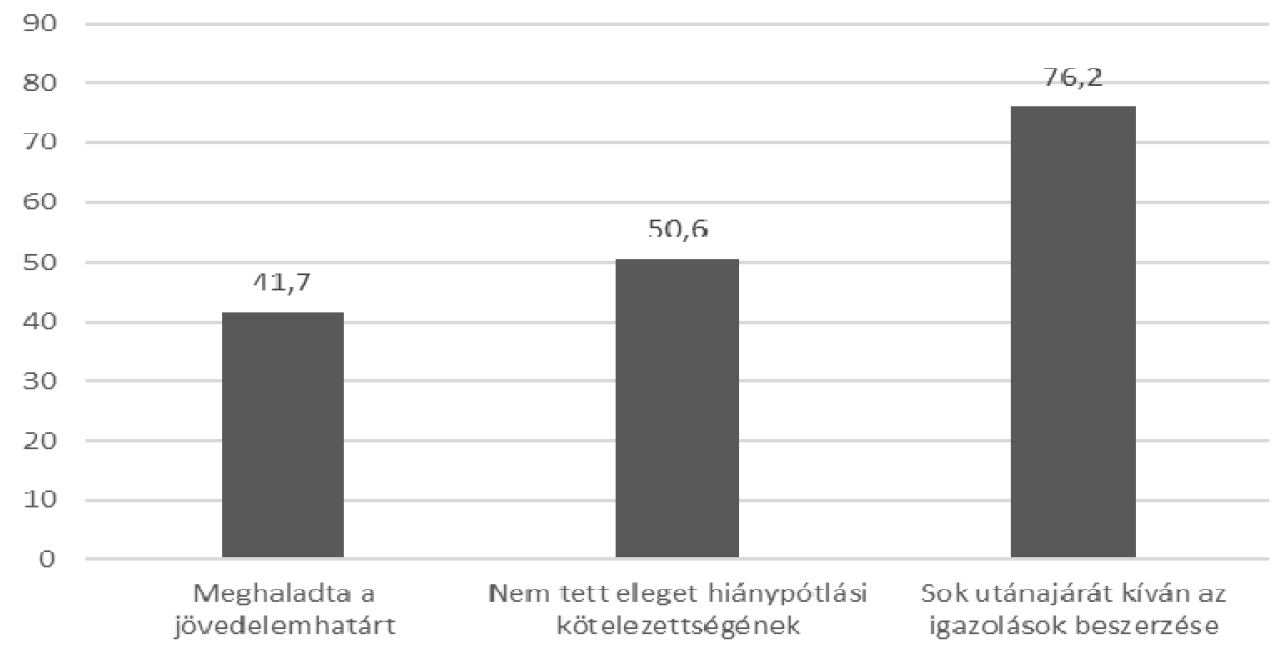

Forrás Nyíregyháza életminösége panelkutatás, 2018

6. ábra Ha segély iránti kérelmét elutasították, mi annak az oka? 2018 \%

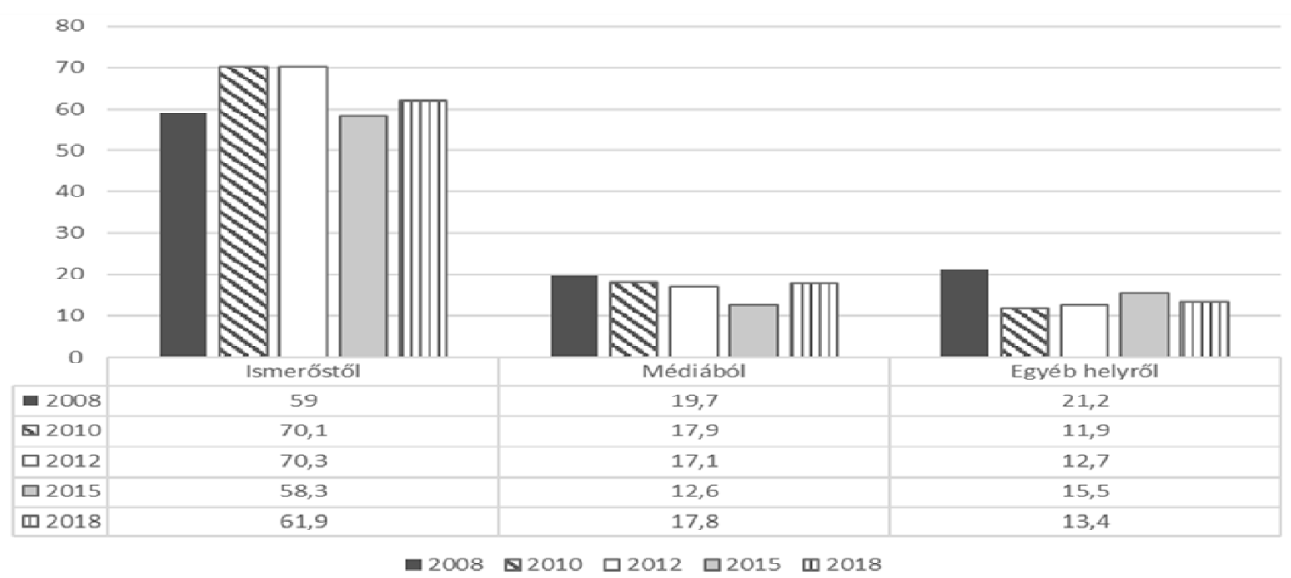

Forrás: Nyirregyháza életminösége panelkutatás, 2008,2010, 2012, 2015, 2018\%.

7. ábra Honnan értesült a segély igénybevételének lehetőségéről?

2008,2010, 2012, 2015, 2018 
Az információhoz való hozzájutás biztosítása alapkövetelmény, amelynek egyik lehetséges eszköze az egyre nagyobb szerepet betöltő internet. A helyi rendeleteket - többek között a pénzbeli és természetbeni ellátásokról szóló rendeletet - jogszabályi (lásd Magyarország helyi önkormányzatairól szóló 2011. évi CLXXXIX. törvény) elöírás alapján az önkormányzatoknak honlapjukon is közzé kell tenni. Arra a kérdésre, hogy honnan értesült a segély igénybevételének lehetőségéről Nyíregyházán az ismerősök mellett, ismét növekedett a média szerepe (7. ábra).

Megoldja-e a segély a problémát? Biztosan állíthatjuk, hogy nem, csak a kezelésére szolgál.

A 8. ábrából jól látható, hogy a megkérdezettek szerint is legalább részben megoldást kínál a kapott támogatás. 2012 évhez képest azonban növekedett azoknak a száma, akiknek véleménye szerint teljes mértékben megoldja a problémát és növekedett azoknak a száma, akik szerint egyáltalán nem nyújt segítséget a támogatás.

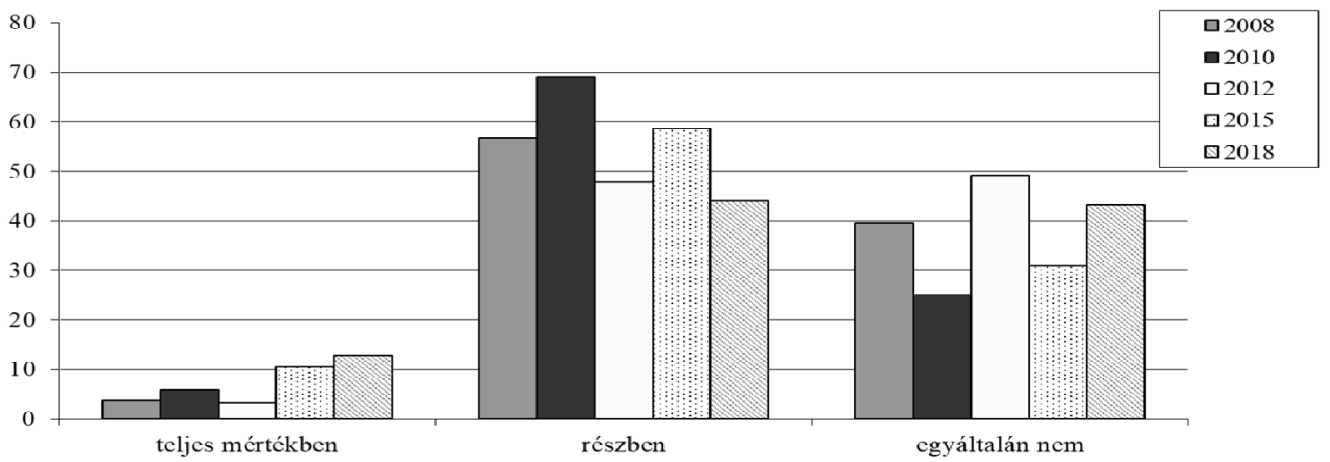

Forrás: Nyíregyháza életminösége panelkutatás, 2008, 2010, 2012, 2015 és 2018

8. ábra . ábra A megállapított segély megoldotta-e problémáját? 2008, 2010, 2012, 2015 és 2018 (\%)

\section{$0.30 \%$}

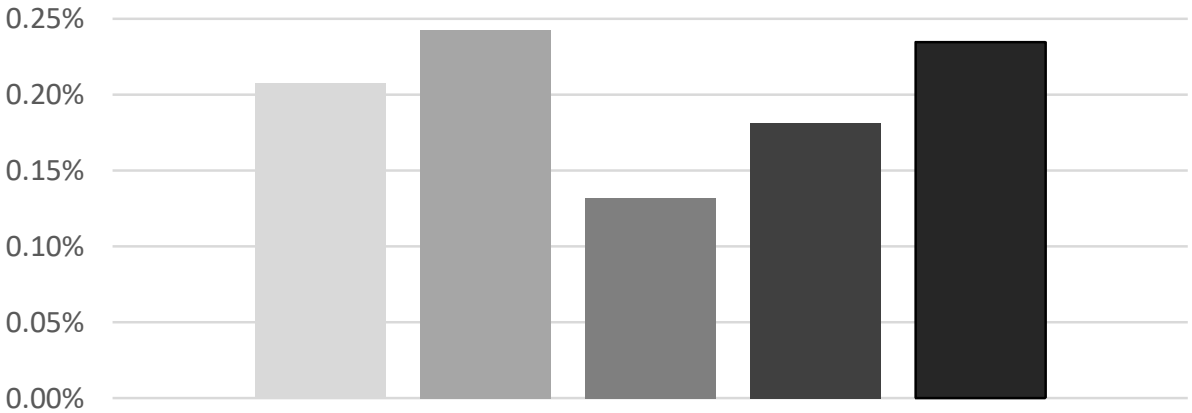

$\square$ 10.000-40.000 Ft között $\square 50.000 \mathrm{Ft} \square 50.001-90.000 \mathrm{Ft} \square 100.000 \mathrm{Ft} \square 100.000 \mathrm{Ft}$ felett

Forrás Nyíregyháza életminösége panelkutatás, 2018

9. ábra Megítélése szerint mekkora összegü segélyre, támogatásra lenne ahhoz szüksége, hogy szociális helyzetében pozitív változás következzen be 2018. (\%) 
Ezzel összefüggésben megnéztük, hogy milyen összeget tartanának elégségesnek a megkérdezettek arra, hogy problémájukat megoldja a válaszadók többsége legalább $50.000 \mathrm{Ft}$-ot és majdnem ugyanennyien $100.000 \mathrm{Ft}$ tartanának szükségesnek (9. ábra).

Ha a fenti adatokat, válaszokat összevetjük, akkor a támogatások iránti igény csökkenése mögött állhat az is, hogy a kapható támogatási összegeket a jobb anyagi helyzetben lévők kevésnek tartják ahhoz, hogy hathatós segítséget nyújtson számukra, ezért nem is igénylik meg azt. Nyíregyházán a legnagyobb támogatási összeg 2018-ban méltányossági ápolási díj 28.500Ft/hó, ezt követően havi 7200 Ft lakásfenntartási támogatásként. Ezt támasztja alá az arra a kérdésre adott válasz is, „Hogyan változtatná meg a segélye való jogosultság feltételeit?” A megkérdezettek 85,6 \%-a probléma jellegéhez, nagyságához igazítaná az adható támogatás mértékét.

A segélyezési rendszerek vizsgálatánál szinte mindig felvetődik, hogy ki ért vele egyet, ki támogatja vagy éppen ellenkezőleg ki szüntetné meg. Már a 2008-2010-es kutatás során is kimutatható volt, hogy „a nyíregyháziak maximálisan elutasítják azt, hogy a segélyezés nem szükséges, azaz „meg kellene szüntetni”, vagy fel kellene számolni (ez a legelutasítottabb kijelentés), illetve egyetértenek azzal, hogy szükség van rá, mert bizonyos problémákat csak ezáltal lehet megoldani.” (10. ábra) (Balogh, Fábián, 2012)

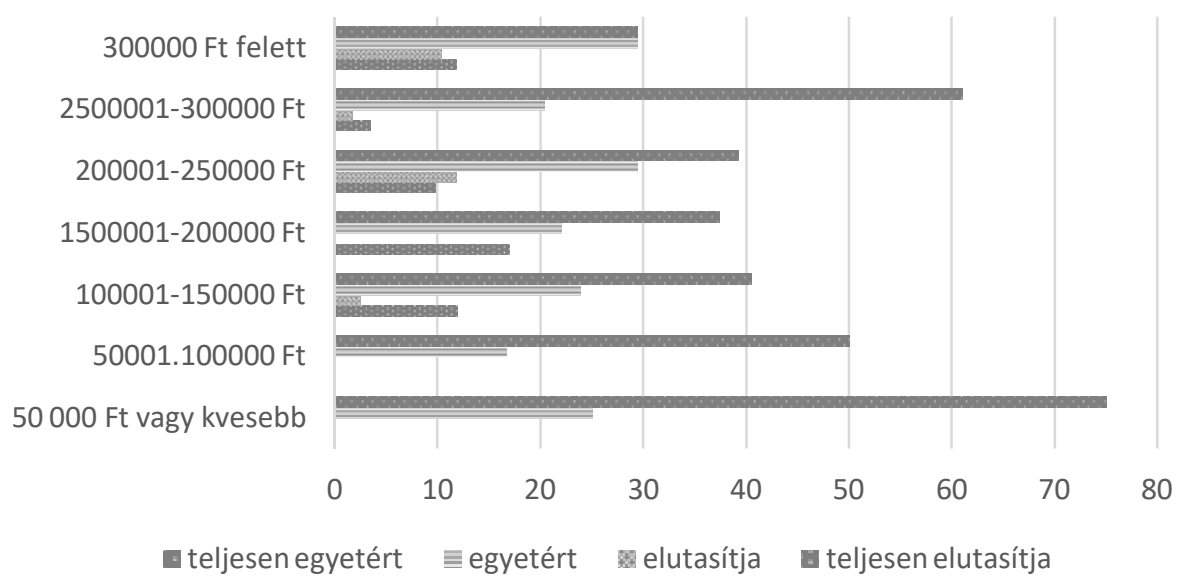

Forrás: Nyíregyháza életminösége panelkutatás, 2018

10. ábra Szükséges a segélyezés, mert bizonyos problémákat csak ezáltal lehet megoldani 2018.

A 2018-ra továbbra is fennmaradt kedvező vélekedéshez hozzájárulhat az is, hogy 2015-től bevezetett változtatásokkal az ügyfelek jövedelmi és anyagi helyzete a különböző nyilvántartásokhoz való hozzáféréssel leellenőrizhető, így egyre kevésbé támadható a segélyezési rendszer azzal, hogy az arra nem jogosultak is kapják.

A segélyezési rendszer fenntartását a lakosságnak a háztartás jövedelmére vonatkozó értékelése is alátámasztja (lásd részletesen Fábián, Takács, Szigeti, 2018). 


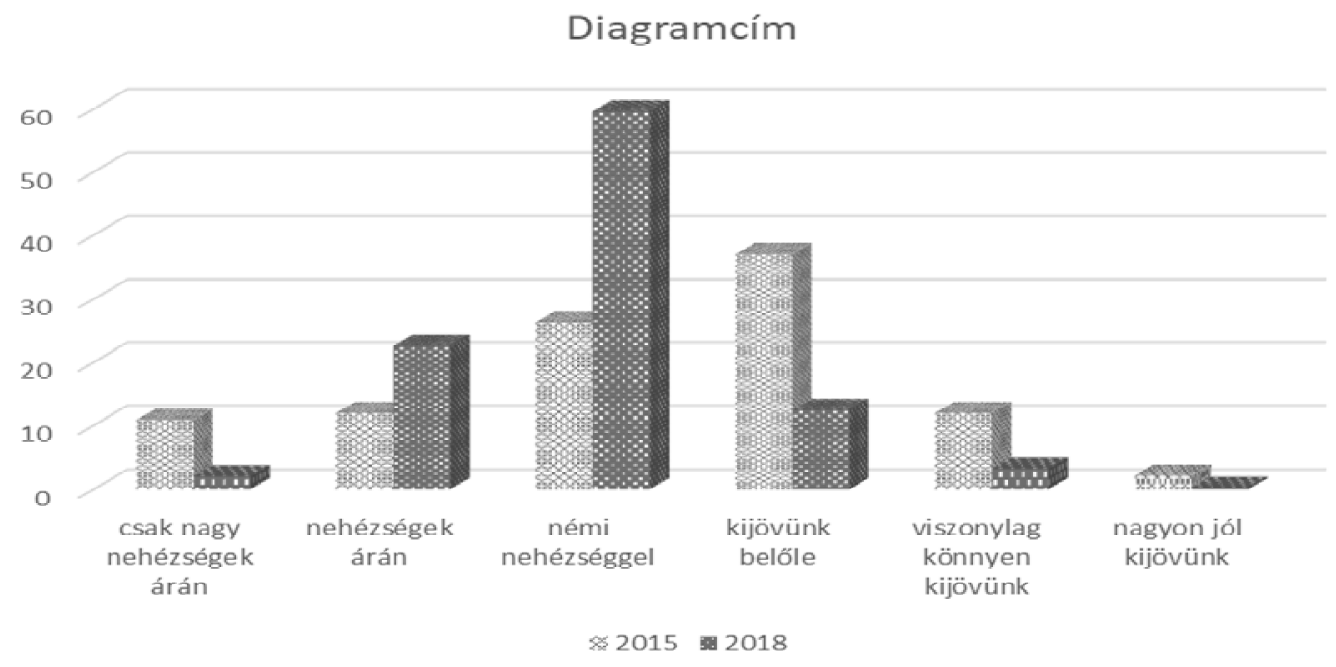

Forrás: Nyíregyháza életminösége panelkutatás, 2015

11. ábra A válaszadók véleménye a háztartás havi jövedelme alapján megélhetésükröl 2015, 2018. (\%)

2015-höz képest több mint duplájára emelkedett azoknak a száma, akik a háztartás jövedelmét figyelembe véve kijönnek belöle, de nehézségek árán, vagyis egy jelentős rétegnek továbbra is szükséges a támogatás (11. ábra).

\section{Összegzés}

Tanulmányunkban a 2008 és a 2018 között végbemenő változásokat igyekeztünk elemezni és keresni azokat az okokat, amelyek elsősorban a támogatások igénylése terén 2012 után, jelentősebben 2016-tól bekövetkezett csökkenés hátterében állnak. Kétségkívül a fent részletezett adatok azt mutatják, hogy kedvező folyamatok mentek végbe városunkban, ugyanakkor egyrészt kialakult egy olyan réteg, akiket folyamatosan támogat önkormányzatunk, másrészt viszont van egy kicsit jobb jövedelmi, anyagi helyzetben lévő réteg, akikhez tartozók annak ellenére nem kérnek segítséget, hogy jogosultak lennének. Véleményünk szerint az egyik ok abban kereshető, hogy annak ellenére, hogy az Internet szerepe felerősödött az információszerzésben és adásban, mégis többen továbbra is inkább ismerőseiktől szereznek információkat, így nem feltétlenül jutnak valós, megbízható ismeretekhez. A kutatás során megkérdezettek $68 \%$-a nyilatkozott úgy, hogy tudja problémája megoldásában kihez, az önkormányzathoz vagy a járási hivatalhoz kell fordulnia, mégsem jutnak hozzá az önkormányzattól kapható támogatásokhoz. Ennek oka lehet, hogy a járási hivatalhoz fordulók (innen kapják a jövedelemkompenzáló támogatásokat) nem feltétlenül kapnak információkat a járás települései, így Nyíregyháza esetén igényelhető támogatásokról sem. 
Megítélésünk szerint az információknak a lakossághoz történő eljuttatásában a szolgáltatóknak nagyobb szerepet kell vállalnia, hiszen ők azok, akik napi kapcsolatban állnak az ügyfelekkel. Ugyanakkor a szolgáltatók sokszínűsége (önkormányzati, civil és egyházi fenntartók), az, hogy ugyanazzal a célcsoporttal több szolgáltató is kapcsolatban áll, mind hozzájárulhat ahhoz, hogy nem jutnak el az információk a rászorultakhoz. Természetesen nehezíti a szakemberek felkészültségét, hogy éppen a segélyezési rendszer átalakításával még több szereplőssé és még átláthatatlanabbá vált az igénybe vehető támogatások köre, a segítséget nyújtók köre. Egyenlöre nem láthatók a közigazgatásban bekövetkezett újítások, az elektronikus ügyintézés, az egyablakos ügyintézés kiterjesztéstől, az ügyek összekapcsolásától várt előnyök sem.

Továbbá figyelembe kell venni azokat a változtatásokat mind kormányzati mind önkormányzati szinten, melynek során számos korábban a rászorultsághoz kapcsolódó ellátás vált alanyi joggá (ingyenes tankönyvellátás, ingyenes étkeztetés kiterjesztése, stb.), települési szinten pedig szintén előtérbe kerültek az alanyi jogon járó juttatások (tanszer támogatás, karácsonyi csomag). ${ }^{8} \mathrm{Az}$ utóbbi folyamatok felerősödésével kialakulhat egy olyan vélekedés, mely szerint, ha valaki alanyi jogon járó juttatások mellett segítséget kér, azzal már „szégyelni való”, rosszabb helyzetét ismeri el (a válaszadók 8,3\%-a azért nem kért segítséget, mert megalázónak tartja).

Jelen írásunkban nem tértünk ki a segélyezés finanszírozási hátterére tekintettel arra, hogy 2015-höz képest (részletesen elemeztük tanulmányunkban) nem történ változás, továbbra is a jó adóerő-képességnek köszönhetően saját forrást kell felhasználnia az önkormányzatnak. Ugyanakkor az országos tendenciához hasonlóan csökkent a felhasznált támogatási összeg 2015-höz (818.903 millió) képest 2018-ra . Figyelembe véve, hogy az önkormányzat nem csökkentette le a felhasznált összeg szintjére a segélyre tervezett rendelkezésre álló keretet, lehetőség kínálkozik egyegy célcsoportot számára célzott támogatási formák kialakítására, mely segítheti, hogy a városban kedvező társadalmi változások menjenek végbe.

\section{Felhasznált irodalom}

1. Balogh E., Fábián G. (2012): Támogató rendszerek, szociális problémák és segélyezés. In: Fábián Gergely, Patyán László, Huszti Éva (szerk.) Életminőség Nyíregyházán. Nyíregyháza: Debreceni Egyetem Egészségügyi Főiskolai Kar, pp. 135-154.

2. Branyiczki R., Gábos A. (2018): A szegénység dinamikája a válság időszakában Magyarországon. Társadalmi Riport 2018., 125-142.

3. Farkas Zs. (2016): A rendszeres gyermekvédelmi kedvezményre jogosult gyermekek, fiatal felnőttek számának csökkenése mögött húzódó okok vizsgá-

\footnotetext{
${ }^{8}$ Vizsgálatunk ezen ellátásokra nem terjedt ki. Szabályozását lásd a szociális rászorultságtól függő egyes pénzbeli és természetben nyújtott szociális ellátásokról szóló Nyíregyháza Megyei Jogú Város Közgyülésének 3/2015. (II. 20.) önkormányzati rendeletében
} 
lata. http://old.tarki.hu/hu/news/2016/kitekint/szocpol/

20160823_szocpol_monitoring_4_farkas.pdf (2019.06.14.)

4. Fábián G., Takács P., Szigeti F. (2015): Jövedelmi helyzet és jövedelmi szegénység. Acta Medicinae et Sociologica Vol. 6. No. 18-19: 68-79.

5. Fábián Gergely, Takács Péter, Szigeti Fruzsina, (2018): Jövedelmi helyzet, jövedelmi egyenlőtlenségek. Acta Medicinae et Sociologica Vol.9. No.27. 58-69.

6. Fábián G., Huszti É., Hüse L., Takács P. (2018): Életminőség Nyíregyházán. A nyíregyházi nagymintás társadalomkutatások első négy hulláma a megyeszékhelyen. Szabolcs-Szatmár-Beregi Szemle 53/3: 83-102.

7. Huszti É., Hüse L., Takács P., Fábián G., (2018): A „Nyíregyháza Életminősége 2018" vizsgálat és a kutatás módszertana. Acta Medicinae et Sociologica Vol.9. No.27. 7-18.

8. Jakab A., Gajduschek Gy. (2016): A magyar jogrendszer állapota. MTA Társadalomtudományi Kutatóközpont, Budapest.

9. Kopasz M., Gábos A. (2018): A szociális segélyezési rendszer 2015. márciusi átalakításának hatása a települési önkormányzatok magatartására. Társadalmi Riport 2018., 328-348.

10. Malakucziné Póka M. (2012): Nyíregyháza lakosságának főbb demográfiai jellemzői Acta Medicinae et Sociologica Vol.3.No.3.

11. Magyarország helyi önkormányzatairól szóló 2011. évi CLXXXIX. törvény 51. $\S(2)$ bekezdés.

12. Patyán L. (2018): Időskorúak életminősége 2008 - 2018. Acta Medicinae et Sociologica Vol.9. No.27. 125-137.

13. Szalai J. (2002): A társadalmi kirekesztődés egyes kérdései az ezredforduló Magyarországán, Szociológiai Szemle 2002/4. 39.

14. Szilicsány É. P. (2015): Megélhetési nehézségek és nélkülözés a Nyíregyházi járásban és nélkülözés a Nyíregyházi járásban. ActaMedicinae et Sociologica Vol. 6. No. 18-19. (2015.) 80-95.

15. Szociális Statisztikai Évkönyv, 2015. http://www.ksh.hu/docs/hun/xftp/ idoszaki/evkonyv/szocialis_evkonyv_2015.pdf (2019.06.14.)

16. Takács P., Fábián G. (2018): Lokális Életminőség Index, Nyíregyháza 2018 valamint a multihalmaz alapú vizsgálatok lehetőségei. Acta Medicinae et Sociologica Vol 9. No. 27. 70-95. 